\title{
Effect of the addition of L-ascorbic acid in megadoses to the diet on the morphology of liver cells in rats*
}

\author{
T. Ostaszewska', E. Sawosz ${ }^{2.4}$, T. Niemiec ${ }^{2}$, J. Skomial ${ }^{2}$ \\ and W. Bielecki $\mathbf{i}^{3}$ \\ Warsan Agricultural Lniversity; \\ 'Division of Ichtiobiology and Fisheries, \\ 'Department of Animal Nutrition and Feed Science, \\ 'Department of Clinical Science \\ Ciszewskiego 8. 02-786 Warsaw, Poland
}

\section{ABSTRACT}

The aim of the study was to determine the ellect of megadoses of 1 -ascorbic acid, as a dietary supplement for rats, on the morphological status of the liver. Forty male rats were divided into 4 groups and fed mixtures that were supplemented with ascorbic acid in the following quantitics in the particular groups (in \% of the mixtures): $1,0.0 ; \mathrm{II}, 0.3 ; \mathrm{III}, 0.6$; and IV, 0.9 . T'he results showed that L-ascorbic acid supplemented to the mixtures at a level of $0.9 \%$ caused necrotic damage of hepatocytes.

KFY WORDS: rats, L-ascorbic acid, hepatocyte, pathomorphology

\section{INTRODUCTION}

Ascorbic acid, the most important antioxidant of the aqueous phase of the body (Banhegyi et al., 1997) counteracts the generation of reactive oxygen species (ROS), consequently preventing the production of toxic compounds causing degradation of cellular structures. Although the majority of animals synthesize $\mathrm{L}$-ascorbic acid, due to environmental stress, production intensity or age, demand for this vitamin may considerably exceed its endogenous synthesis. Megadoses of vitamin $\mathrm{C}$ are employed in human and animal nutrition for prophylactic and therapeutic purposes. However, the pro-oxidative effects of vitamin $\mathrm{C}$ often observed in in vitro studies (Paolini et al., 1999) raise constant controversies concerning its influence on homeostasis of the organism (Podmore et al., 1998).

\footnotetext{
"Supported by the State Committee for Scientific Research, Grant No. 6 P06 P02720

${ }^{4}$ Corresponding author: e-mail: sawos $2(a$ alpha.sggw.waw.pl
} 
The aim of the conducted studies was to determine the effect of megadoses of Lascorbic acid added to diets for rats on the morphological status of the liver.

\section{MATERIAL AND METHODS}

Forty growing male Wistar rats (average initial body weight $235.0 \mathrm{~g}$ ) were divided into 4 groups $\times 10$ animals and were kept in individual cages for 41 days under standard conditions: temperature $22^{\circ} \mathrm{C}$, air humidity, $50-70^{\circ}$, light/dark $12 / 12 \mathrm{~h}$. The rats received semi-purified mixtures containing (in \%): maize starch I, 62.22; II, 61.92; III, 61.62; IV, 61.32; casein, 14.0; sucrose, 10.0; cellulose, 5.0; rapeseed oil, 5.0; mineral mix, 3.5; vitamin mix, 1.0; L-cystine, 0.18 ; and choline chloride, 0.1 . The mixtures were supplemented with ascorbic acid in groups (in \% of the mixtures): I, 0.0 ; II, 0.3 ; III, 0.6; and IV, 0.9. L-ascorbic acid, mineral and vitamin mixtures were obtained from ICN Biomedicals. After the experiment, the rats were euthanised by an overdose of ketamine and immediately after sacrifice, samples of liver were collected from the right lobe, $1 \mathrm{~cm}^{3}$ on average. They were fixed in 10-\% neutral buffered formalin, embedded in paraffin, sectioned at $6 \mu \mathrm{m}$ and stained with haematoxylin-eosin and periodic acidSchiff (PAS). The samples for determination of fat were frozen, sectioned and stained using Sudan III. The cells in one field were counted, using $50 \times$ magnification. Detailed examination of the cells was performed under $400 \times$ magnification.

The results were analysed by one-way analysis of variance ANOVA, using the Statgraphics 4.1 computer program.

\section{RESULTS AND DISCUSION}

The histopathological picture of the liver of rats from groups I and III shows the normal structure of liver lobes and hepatocytes with a typical morphology (Figure 1). Single necrotic hepatocytes are visible within the particular lobes. In the liver of rats from groups II and IV, the histomorphological structure is preserved, but focal necrosis of hepatocytes is seen (about 25\%) (Figure 2). In group IV, the smallest

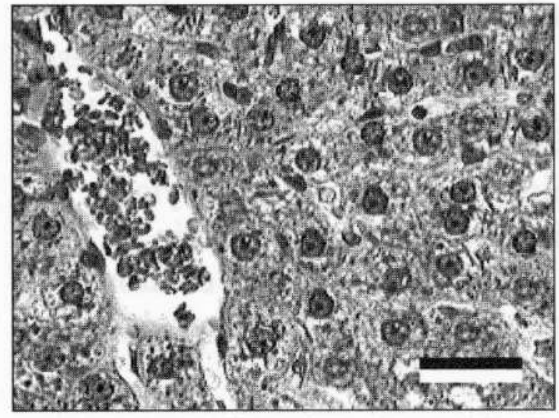

Figure 1. Normal liver of rats (group 1) (H-E, Bar $5 \mu \mathrm{m})$

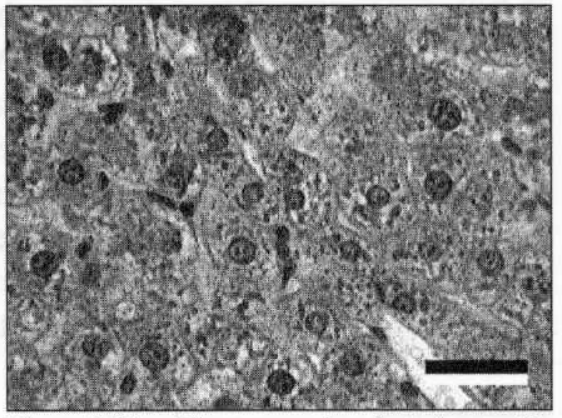

Figure 2. Focal liver necrosis of rats (group 4) $(\mathrm{H}-\mathrm{E}, \mathrm{Bar} 5 \mu \mathrm{m})$ 
number of two-nuclei hepatocytes was observed (Table 1). The lowest number of cells was found in group IV and the largest hepatocytes were in group II.

TABLE 1

Morphometry of cells and percentage of cells with different number of nuclei in the liver of examined rats

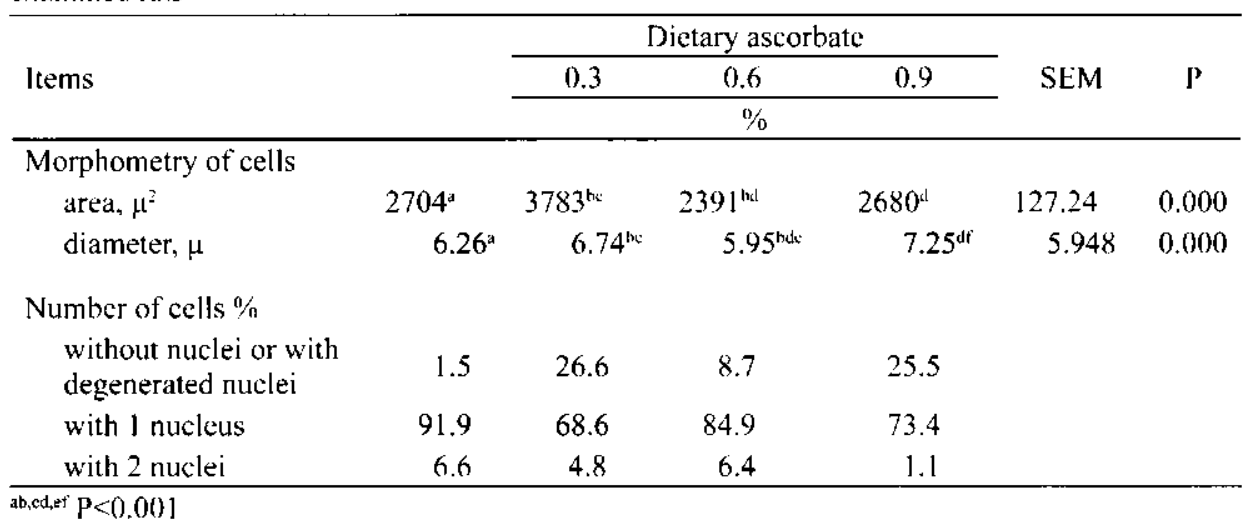

The anti-oxidative properties of ascorbic acid lic in its strong reducing capacities. An excessive level of reduction may be, however, the reason for generation of excessive quantities of reduced metal ions in the organism, which may stimulate the Fenton reaction, and by this, synthesis of the most aggressive hydroxyl radical (Levine et al., 1998). Generation of the hydroxyl radical leads to degradation of most cellular structures, including DNA (Halliwel, 1996). A considerable quantity of necrotic hepatocytes in those rats receiving 0.3 and $0.9 \%$ ascorbic acid in the mixtures, as observed in the present experiment, is undoubtedly evidence of cell degradation caused by the administered vitamin C. The pro-oxidative effect of vitamin $\mathrm{C}$ has been demonstrated in vitro (Carr and Frei, 1999). However, according to some authors, megadoses of vitamin C have been used in the treatment of cancer. The investigations of Shamaan ct al. (1998) showed that numerous neoplastic nodules, stimulated in the liver, seemed to decrease after vitamin $C$ supplementation. The cited studies focused on the decrease in the number of two-nuclei cells and increase of necrotic cells in the liver after supplementation of $0.9 \%$ ascorbic acid. It seems that the pro-oxidative properties of vitamin $\mathrm{C}$ observed in healthy rats might be beneficial in cancer. This type of action of ascorbate may explain the anticancer properties of vitamin $\mathrm{C}$. The obtained results concerned, however, healthy rats; the effect of vitamin $\mathrm{C}$ may probably cause neoplastic cell damage.

Vitamin $\mathrm{C}$ at a $0.6 \%$ level did not result in degradation of hepatocytes, which supports previous results obtained by authors who found that mixtures supplemented with $0.6 \%$ vitamin $C$ did not increase the serum level of $L$-ascorbic 
acid or total antioxidant status in comparison with 0.3 and $0.9 \%$ vitamin $\mathrm{C}$ in the mixtures (Niemiec and Sawosz, 2004).

\section{CONCLUSIONS}

It may be concluded that the results obtained in our experiments show that L-ascorbic acid supplemented to mixtures at a level of $0.9 \%$ caused necrotic damage to liver cells.

\section{REFERENCES}

Banhegyi G. Braun L., Csala M., Puskas F., Mandl J., 1997. Ascorbate metabolism and its regulation in animals. Free Radical Biol. Med. 23, 793-803

Carr A., Frei B., 1999. Does vitamin $C^{-}$act as pro-oxidant under physiological condition. FASEB J. $13,1007-1024$

llalliwell B., 1996. Vilamin C: antioxidant or pro-oxidant in vivo? liree Rad. Res. 25, 439-454

Levine M., Daruwala R.C., Park J.B.. Rumsey C.S.. Wang Y., 1998. Does vitamin C have a prooxidant effect? Nature 395,231

Niemiec T., Sawosz F, 2004. Eflect of addition of L-ascorbic acid megadoses to the diets on the antioxidative-oxidative state in rats. Proccedings of 8 International Conference of Furopcan Society of Veterinary and Comparative Nutrition. Budapest, pp. 258-259

Paolini M., Pozzetti I., Pedulii G.F., Marchesi F., Cantelli-Forti G., 1999. The nature of prooxidant aclivity of vitamin C. L ife Sci. 64. 273-278

Podmore I.D., Grilfiths H.R., Herbert K.E., Mistry N., Mistry P., Lunec J., 1998. Vitamin C exhibits pro-oxidant properties. Nature 392,559

Schamaan N.A., Kadir K.A., Rahmat F.A., Ngah 7.., I998. Vitamin C and Aloc Vera supplementation protect lirom chemical hepatocarcinogenesis in the rat. Nutrition 14, 846-852

\section{STRESZCZFNIE.}

\section{Wpływ dodatku megadawek kwasu L-askorbinowego do diety na morfologiç komórek wątroby szezurów}

Celem podjętych badań byla ocena wpływu dicty zawicrającej megadawki kwasu 1.-askorbinowego na morfologiç wątroby szczurów. Doświadczenie przeprowadzono na 40 samcach szczurach rasy Wistar. Zwierzęta podzielono na 4 grupy i żywiono mieszankami, którc różnily się zawartością kwasu L-askorbinowego w diccic ( $w \%$ : I - 0,0; II - 0,3: III - 0,6 j IV-0,9. Na podstawie uzyskanych wyników stwierdzono, że dodatck kwasu L-askorbinowego do mieszanki $(0.9 \%)$ wywolal uszkodzenia nekrotyczne komórek wątroby. 